\title{
Application of Remote Sensing and GIS for Improving Rice Production in Flood-prone Areas: A Case Study in Lower Chi-River Basin, Thailand
}

\author{
Chattichai WAISURASINGHA ${ }^{1 *}$, Masamu ANIYA ${ }^{2}$, Akira HIRANO ${ }^{3}$, Janya \\ SANG-ARUN ${ }^{4}$ and Wilailak SOMMUT ${ }^{5}$ \\ ${ }^{1}$ Faculty of Engineering, Khon Kaen University (Muang, Khon Kaen 40002 , Thailand) \\ ${ }^{2}$ Graduate School of Life and Environmental Sciences, University of Tsukuba \\ (Tsukuba, Ibaraki 305-8572, Japan) \\ ${ }^{3}$ Development Research Division, Japan International Research Center for Agricultural Sciences \\ (JIRCAS) (Tsukuba, Ibaraki 305-8686, Japan) \\ ${ }^{4}$ Graduate School of Frontier Science, The University of Tokyo (Kashiwa, Chiba 277-8563, Japan) \\ ${ }^{5}$ Prachinburi Rice Research Center, Rice Research Institute (Ban-Sang, Prachinburi 25150, Thailand)
}

\begin{abstract}
Rice is annually destroyed by seasonal flooding in South and Southeast Asia. In order to reduce the loss of rice production, an accurate assessment of flood-affected paddies is essential. Taking the 2001 monsoon flooding that hit the Lower Chi River Basin, northeastern Thailand, as a case study, we derived the flood depth over the large and inaccessible areas using a RADARSAT-1 image acquired during the flooding peak and a 30-m Digital Elevation Model. Based on the elongation properties of rice, we used the critical water-depth of $80 \mathrm{~cm}$ to classify the flood-affected paddies into 'damaged' or 'non-damaged' paddies. Our results show that only about $40 \%$ of the flood-affected paddies were actually damaged paddies. In addition, we analyzed the damaged paddies by overlaying the derived water depth with the flood frequency map in order to recommend planting the appropriate rice varieties. Our analysis reveals that remote sensing and GIS can be used to minimize the loss of rice production and thus help farmers to increase their income in the long run, which will save the government money paid in flood compensations.
\end{abstract}

Discipline: Agricultural engineering

Additional key words: flood, rice varieties, water depth

\section{Introduction}

Rice is the staple food for approximately half of the world's population ${ }^{3}$. During the last decade, about $70 \%$ of the global rice trade has been exported from South and Southeast Asian countries ${ }^{26}$. However, millions of the farmers in these countries lose their rice production worth over US\$ 1 billion due to monsoon flooding annually ${ }^{28}$. For instance, Thailand, the world's largest rice exporter, is often affected by seasonal flooding, resulting in reduced rice production ${ }^{23,26}$.

One of the most important rice producing areas in Thailand is the Chi River, a tributary of the Mekong River, which is prone to frequent flooding due to flat topography ${ }^{2,9}$. Especially, in the lower part of the Chi River Basin, floodwater can stay for a period of 3-5 months, because the flooded area is mostly underlain by clayey soil with very low permeability $\left(<10^{-7} \mathrm{~mm} / \mathrm{sec}\right)^{12}$. Farmers in this area prefer growing lowland rice, which commands the highest price, but can survive in water depths of only up to $80 \mathrm{~cm}^{19,24}$. Thus the rice here is susceptible to flood damages, when flood depth exceeds the critical depth of $80 \mathrm{~cm}$ for more than a week or two $\mathrm{o}^{25,27,28}$.

Recent studies noted that rice production even in the prolonged flood areas where the water depth exceeds 80 $\mathrm{cm}$ could be salvaged, if the planted rice has appropriate elongating ability with increasing water depth ${ }^{20,23}$. Rice can be classified into three types based on its elongating ability (Fig. $1 \&$ Table 1): (1) non-elongating types (lowland rice) with the tolerance of a maximum water depth of up to $80 \mathrm{~cm}$; (2) slow-elongating types $(2-3 \mathrm{~cm} /$ day, deepwater rice), suitable for water depths ranging from 80 to $150 \mathrm{~cm}$; and (3) fast-elongating types $(15-25 \mathrm{~cm} /$ day,

*Corresponding author: e-mail fcecws@kku.ac.th

Received 1 May 2007; accepted 14 December 2007. 


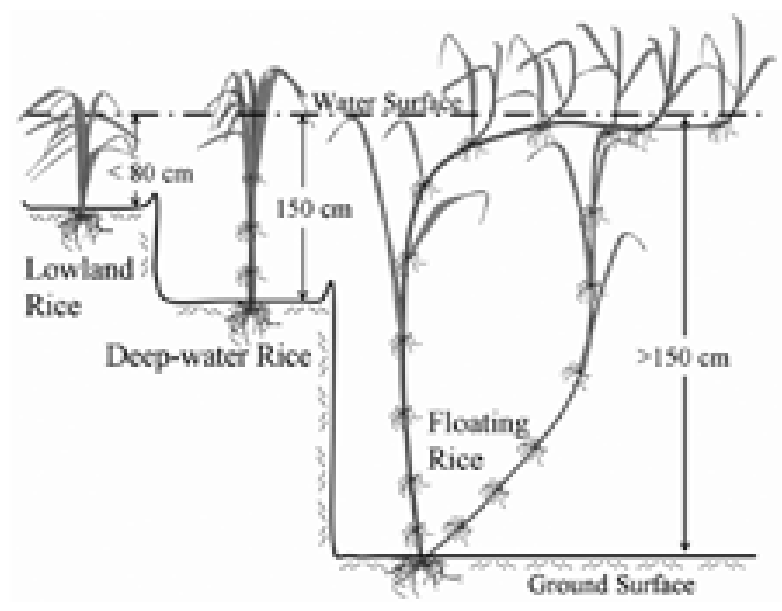

Fig. 1. Rice varieties grown in Thailand and their water-depth tolerance

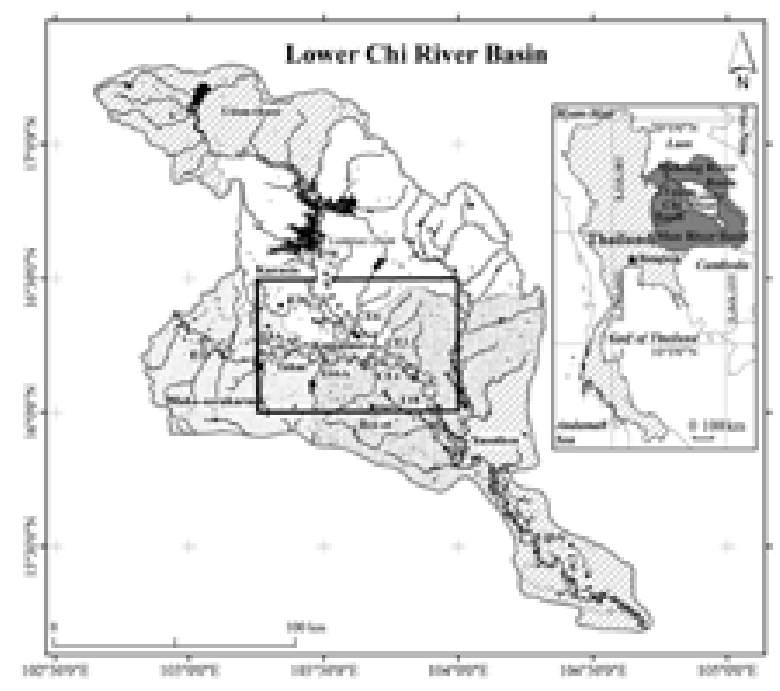

Fig. 2. The study area in the lower part of the Chi River Basin in Thailand

Figure legend:

$\otimes$ : River water gauge station, $\nabla$ : Kamalasai weather station, $\square$ : Study area, $\square$ : Reservoir,

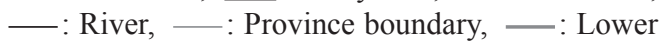
Chi River Basin boundary.

Province legend:

$\square$ : Karasin, $\square$ : Maha-sarakarm, $\square$ : Roi-et, : Others. floating rice), suitable for water depths of more than 150 $\mathrm{cm}^{1,8,20}$.

In terms of its texture, deep-water and floating rice are hard, while lowland rice such as KDML105 and RD6 are soft and aromatic ${ }^{7,10,11,23}$. Consequently, the demand and the market price of lowland rice are higher than the other rice varieties ${ }^{23}$. For these reasons, in the Lower Chi River Basin, farmers prefer planting lowland rice instead of deep-water and floating rice despite the flood damage risk $^{23,25}$. In order to encourage farmers to grow the appropriate rice varieties that can possibly reduce the loss of rice production due to flooding, we need to accurately assess the water depth of flood-affected paddies ${ }^{23}$.

Remote sensing imagery such as Synthetic Aperture Radar (SAR) data is important for providing synoptic coverage over a wide area in all weather conditions ${ }^{18}$. In addition, a geographic information system (GIS) can be used to analyze remote sensing data for estimating flood damages ${ }^{21,22}$. Thus the use of remote sensing and GIS could facilitate the accurate, cost-effective assessment of flood-affected paddies over large and inaccessible $\operatorname{areas}^{13,14,17}$. Integrating a SAR image with a Digital Elevation Model (DEM) can provide important information such as water depth for flood analysis. The objectives of this study are, taking the 2001 flood in the Lower Chi River Basin as a case: (1) to assess flood-affected paddies using remote sensing and GIS, and (2) to recommend appropriate rice varieties for the flood-damaged paddies in order to minimize the loss of rice production.

\section{Study area}

The extent of the study area is $103^{\circ} 15^{\prime} \mathrm{E}$ and $104^{\circ} 00^{\prime}$ $\mathrm{E}$ and between $16^{\circ} 00^{\prime} \mathrm{N}$ and $16^{\circ} 30^{\prime} \mathrm{N}$ (Fig. 2), covering an area of 311,500 ha of the Lower Chi River Basin, which is one of the most important rice hubs for the domestic market in Thailand. Ground elevation ranges from 133 to $359 \mathrm{~m}$ above mean sea level (msl), with the mean annual rainfall of about $1,800 \mathrm{~mm}$. Based on statistical records from 2000 to 2005, all rice grown in this area are lowland rice varieties such as RD6 (49\%), KDML105 (42\%) and RD15 (9\%) $)^{15,19}$.

Table 1. Comparison of elongating ability, water depth tolerance and net income of rice varieties cultivated in Thailand

\begin{tabular}{lccc}
\hline \hline Elongating ability & Water-depth tolerance $(\mathrm{cm})$ & Rice variety & Net income rate* $($ US $\$$ ha $)$ \\
\hline Non-elongating & $<80$ & Lowland rice & 106.62 \\
\hline Slow-elongating $(2-3 \mathrm{~cm} /$ day $)$ & $80-150$ & Deep-water rice & 80.38 \\
\hline Fast-elongating $(15-25 \mathrm{~cm} /$ day $)$ & $>150$ & Floating rice & 59.56 \\
\hline
\end{tabular}

Source: Prachinburi Rice Research Center, Department of Agriculture in Thailand.

*: US\$ $1=45$ Thai Baht. 
In 2001, excessive rainfall started in May due to a local low-pressure system (Fig. 3(a)), and the water level continued to increase due to floodwater from the upper regions. The maximum water level of about $138 \mathrm{~m} \mathrm{msl}$ (normal $132 \mathrm{~m} \mathrm{msl}$ ) was reached in mid-September at station E66A (Fig. 3(b)).

\section{Materials and methods}

A RADARSAT scene (13 September 2001) during the flooding peak (see Fig. 3(b)) and a 30-m DEM derived from digital aerial photogrammetry in 2000 by the Royal Thai Survey Department were used to estimate the water depth for flood-affected paddy assessment. In order to evaluate the accuracy of the interpolated water levels, we used records at eight gauging stations. In addition, 95 water depths were collected in the field by leveling staff, measuring the water-mark smeared on the telephone/ power-line poles by the local government officer in early September 2001 that was coincident with the highest water-level period, and their horizontal positions were located using GPS (see Fig. 6).

For the accuracy assessment of the flood-affected paddy map, pan-sharpened Landsat-7 data (23 November 2001) during the harvesting season was used as the reference data. To recommend the appropriate rice varieties, a digital map layer of flood frequency in a GIS format, which was produced in 2005 by the Land Development Department using multi-temporal remote sensing and hydrological data, was overlaid on the flood-affected paddy map.

\section{Flood-affected paddy assessment based on selected ground observation}

In late August 2001, a seasonal flood hit the Lower Chi River Basin. In order to determine the amount of compensation, the government classified paddies from selected ground observations and village-head reports into 'flooded' or 'non-flooded areas"6. It was assumed that all the rice planted in the flooded areas was completely lost, and the government compensated farmers for loss. In this process, however, due to difficult access to some areas, the evaluation of damaged paddy areas was normally overestimated. The Department of Agricultural Extension reported that 35,477 ha of rice were lost and at a compensation rate of $33.75 \mathrm{US} \$ /$ ha, the government spent a total of US\$ 1.19 million (US\$ 1 equals to 45 Thai Bahts in $2001)^{6}$.

\section{Remote sensing for assessing flood-affected paddies}

During the cloud-veiled monsoon season,
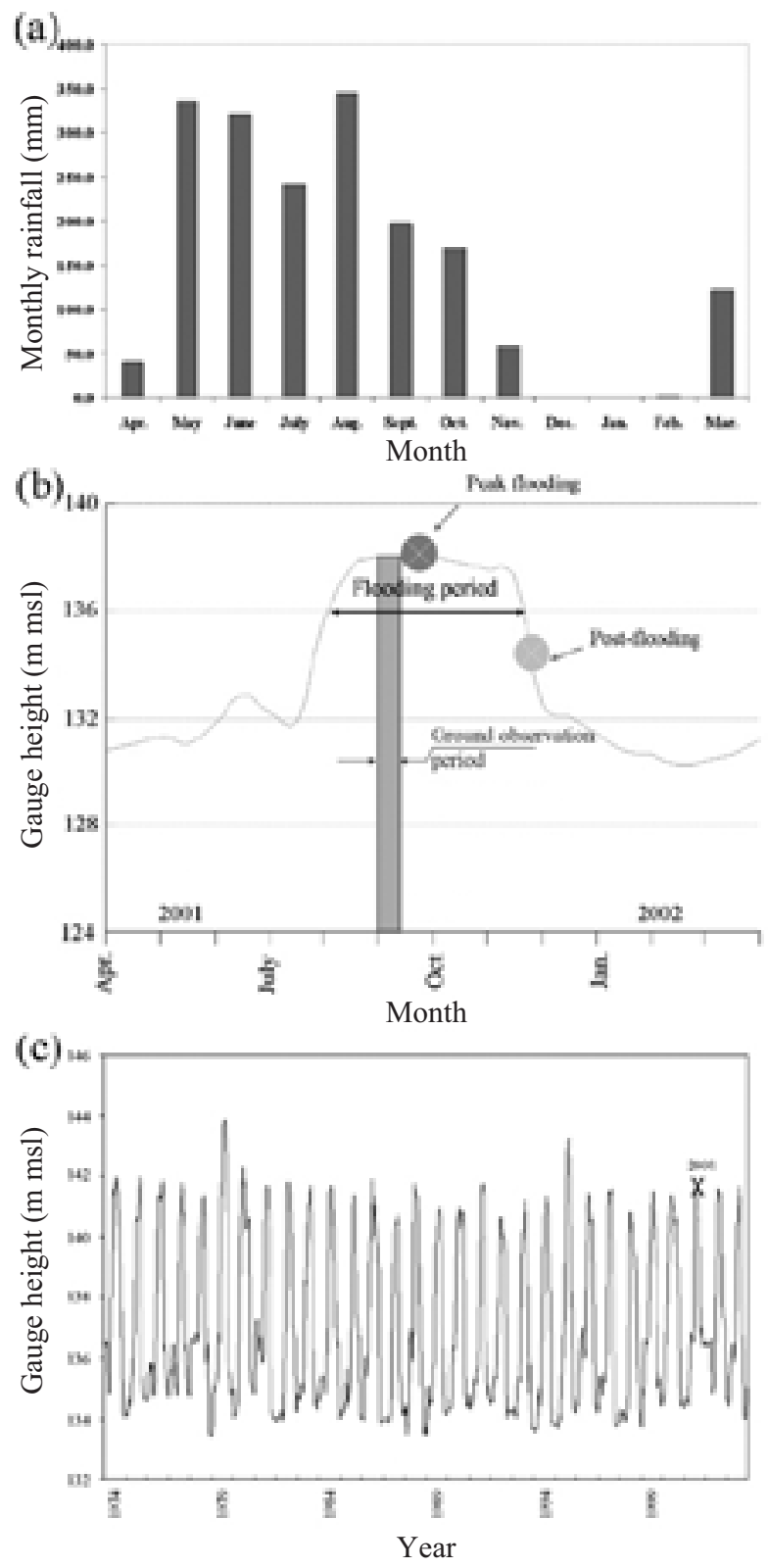

Fig. 3. (a) Monthly rainfall at Kamalasai weather station together with (b) water height at the E66A gauge station from April 2001 to March 2002 and (c) a 30year time series of water heights at the gauging station E8A, which was measured from 1974 to 2003

: RADARSAT data acquisition time.

: Landsat ETM+ data acquisition time.

Source: Royal Irrigation Department of Thailand, 2004.

RADARSAT SAR data can be effectively utilized to map the flood-affected paddies ${ }^{14,18,22}$. The RADARSAT scene was rectified to the same coordinate system of the DEM (UTM WGS84) using a first-order polynomial equation (Fig. 4(a)). Subsequently, the maximum likelihood classification of 'flooded' (blue in Fig. 4(b)) and 'non-flooded' 
C. Waisurasingha et al.
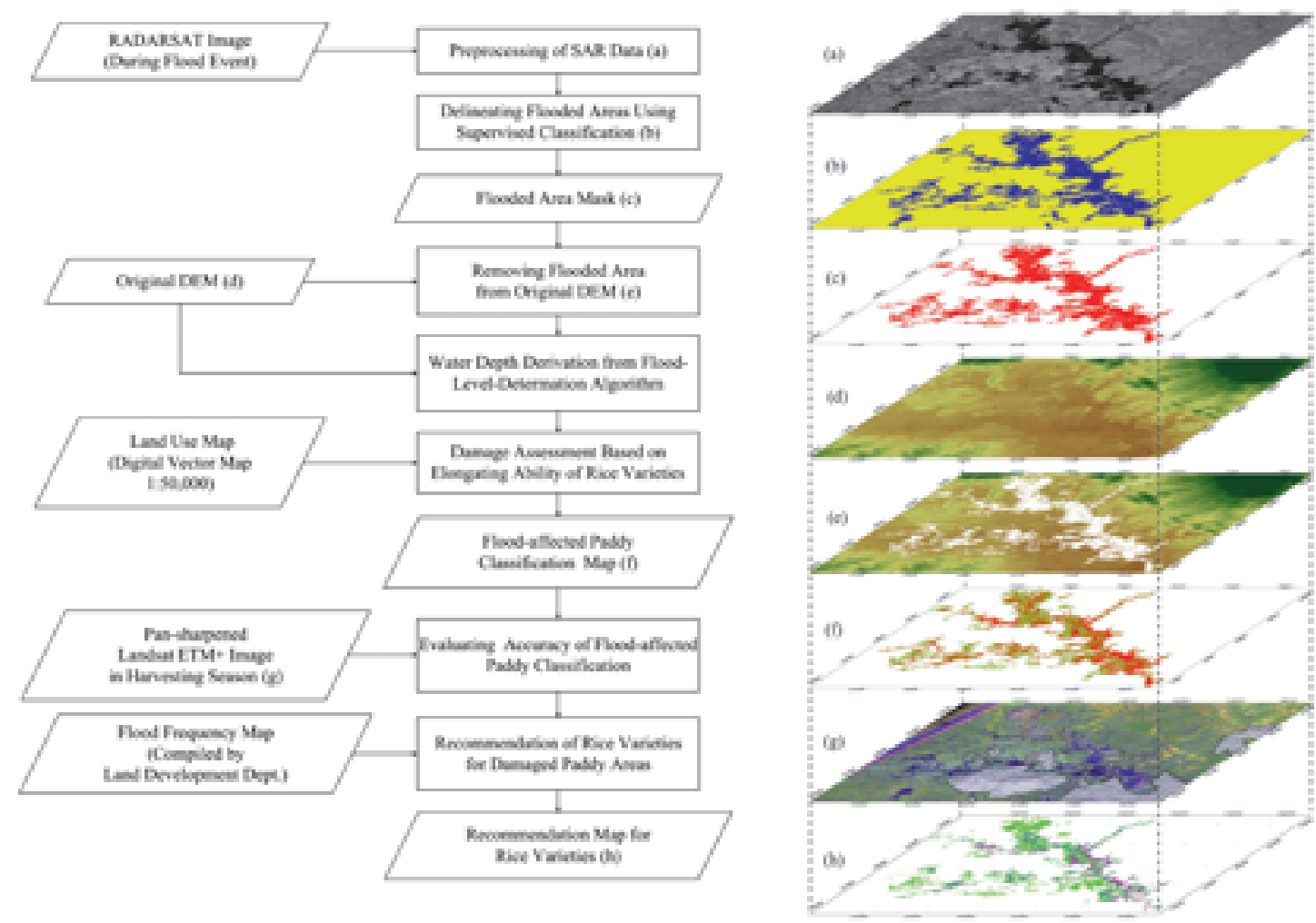

Fig. 4. Flow diagram of procedures for deriving water depth to assess flood-affected paddies and to recommend appropriate rice varieties


Fig. 7. (a) Classification of flood-affected paddies and

(b) flood-frequency map

(a): $\square$ : Non-damaged paddy area (Water depth $\leq 80 \mathrm{~cm}$ ), : Damaged paddy area (Water depth $>80 \mathrm{~cm}$ ), : Pond, $\square$ : Marsh, — : River, ...... Ditch.

(b): $\square$ : Frequent flooding (8 to 10 times in 10 years), : Flooding every two years (4 to 8 times in 10 years), : Infrequent flooding (less than 4 times in 10 years).

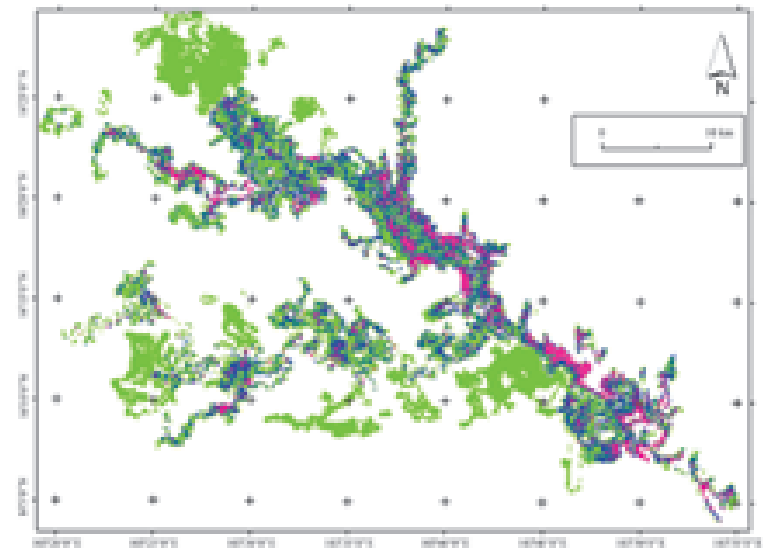

Fig. 8. Map showing rice varieties recommended for the Lower Chi River Basin

$\square$ : Rain-fed lowland rice (Non-elongating rice varieties),

: Deep-water rice (Slow elongating rice varieties),

: Floating rice (Fast elongating rice varieties). 


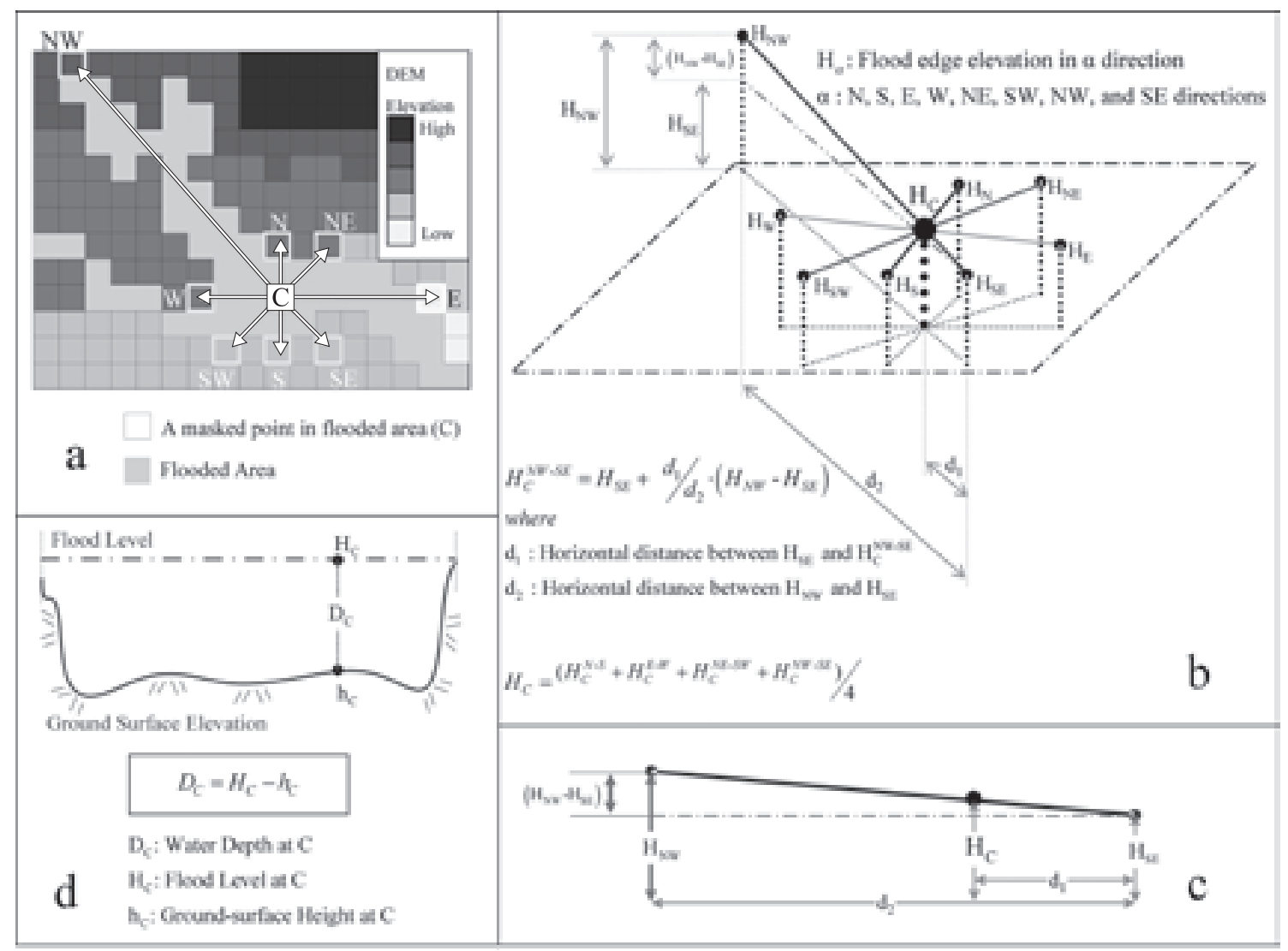

Fig. 5. Algorithm proposed for flood level determination

areas (yellow in Fig. 4(b)) was carried out, resulting in the total flooded areas of 38,130 ha or $12 \%$ of the study area. Overlaying the flooded areas with a land use map (produced in 1999 by the Royal Thai Survey Department) indicates that 34,460 ha or $90 \%$ of the flooded areas were paddy fields.

When the water level stays high for more than a week or two, which was partly caused by the underlying impermeable clayey soil ${ }^{12}$, completely submerged lowland rice cannot survive ${ }^{28}$. Thus, for evaluating the flood-affected paddy conditions, water depth is the most important factor along with the elongating properties of the rice, so that the area classified as 'flooded' (Fig. 4(c)) was masked from the original DEM (Fig. 4(d)) to derive the water depth.

(1) Derivation of water-depth

Because even the flood water surface has a gradient, the level of the flood edge is not the same everywhere. During the 2001 flood, the range of water gauge levels was approximately $9 \mathrm{~m}$, which is extremely crucial for lowland rice ${ }^{23}$. Thus, an accurate estimation of the flood levels is critical for assessing flood-affected paddies, and we developed a 'flood-level-determination' algorithm.

Referring to Fig. 5, for any point C (Fig. 5a) within the flooded area whose DEM was masked (see Fig. 4(e)),

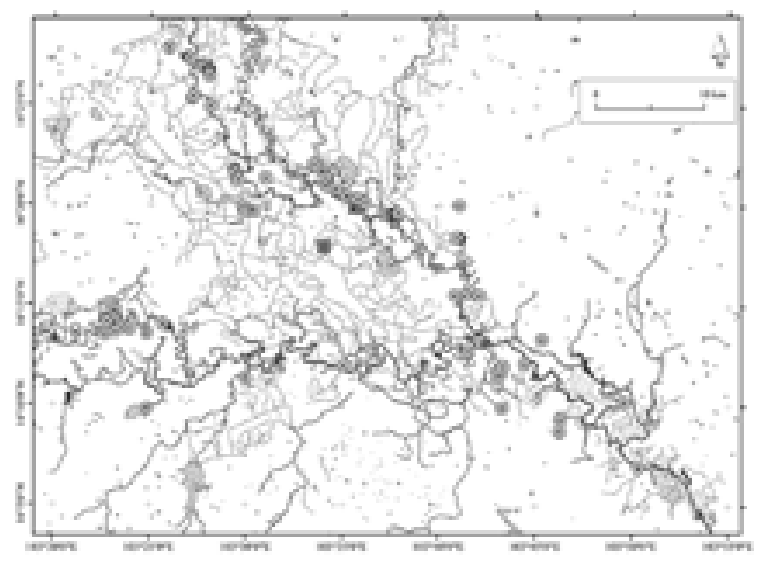

Fig. 6. Spatial distribution of water depth data and gauging stations

e: Water depth data, «: Gauging station,

a: Kamalasai weather station,

$\square$ : Pond, $\square$ : Marsh, — : River, ...... : Ditch.

four lines (N-S, E-W, NW-SE, and NE-SW) are formed (Fig. 5b), with which to interpolate water level by the distance weighting (Fig. 5c). By taking an average of the four interpolated water levels, the flood level $\left(\mathrm{H}_{\mathrm{c}}\right)$ was determined, and the subtraction of the original DEM $\left(h_{c}\right)$ yielded the water depth $\left(D_{c}\right)$ (Fig. 5d). 
The comparison between the estimated water levels and the headwater records at eight gauge stations (see Fig. 6) observed on 13 September 2001 resulted in the range of $-25 \mathrm{~cm}$ to $6 \mathrm{~cm}$, indicating that the 'flood-level-determination' algorithm worked very well (see Table 2). The 95 highest levels of water were observed in the field in two weeks prior to the RADARSAT data. Since the flood level was stable (see Fig. 3(b)), a maximum of a two week difference does not affect the accuracy analysis. Therefore, we compared the estimated and headwater records using the 95 water depth data obtained from fieldwork (Fig. 6). We observed a RMSE of $\pm 14 \mathrm{~cm}$ that satisfies the accuracy requirements for flood assessment ${ }^{16,21}$.

Based primarily on the inundation tolerance of the lowland rice, we classified the flood-affected paddies into two categories: (1) 'damaged paddies' (red in Fig. 4(f)), water depths greater than $80 \mathrm{~cm}$; and (2) 'non-damaged paddies' (green in Fig. 4(f)), water depths of up to $80 \mathrm{~cm}$. It was found that 14,000 ha or $41 \%$ was the damaged paddies mainly located in the central and southeastern parts due to low elevation of the land and meandering of rivers and streams, whereas 20,460 ha or $59 \%$ of the floodaffected paddies was the non-damaged paddies, which were mostly located in the northwestern and western parts (Fig. 7(a)).

(2) Classification accuracy of flood-affected paddies

It has been suggested that a minimum of 50 stratified random sampling points of each land-cover category be included in the confusion matrix ${ }^{4}$. Using 300 randomly sampled points (more than 120 points per class) the classification accuracy of flood-affected paddy was evaluated with a pan-sharpened Landsat ETM+ (band 7, 5, 3) color composite imagery that was acquired during the harvesting season. The stratified random sampling design was adopted, where points were stratified according to the category of the flood-affected paddies. The damaged paddies appeared as bare land or water area while the nondamaged paddies had the color, tone and texture similar to those of the 'non-flooded paddies'. The overall classification accuracy of the flood-affected paddy areas was $87 \%$ with a Kappa index of agreement of 0.73 (Table 3). In terms of the producer's and user's accuracies, non-dam-

Table 2. Comparison of water gauge heights (Sept. 13, 2001) and interpolated water heights

\begin{tabular}{cccc}
\hline \hline Gauge station & $\begin{array}{c}\text { Water gauge height } \\
(\mathrm{m})\end{array}$ & $\begin{array}{c}\text { Interpolated water height } \\
(\mathrm{m})\end{array}$ & $\begin{array}{c}\text { Water height difference } \\
(\mathrm{m})\end{array}$ \\
& $(\mathrm{A})$ & $(\mathrm{B})$ & $(\mathrm{B}-\mathrm{A})$ \\
\hline E18* $^{*}$ & 132.60 & 132.35 & -0.25 \\
$\mathrm{CE}^{\dagger}$ & 134.52 & 134.37 & -0.15 \\
$\mathrm{CE}^{\dagger}$ & 135.28 & 135.22 & -0.06 \\
Tahae $^{\dagger}$ & 137.58 & 137.63 & 0.05 \\
$\mathrm{CE6}^{\dagger}$ & 137.62 & 137.56 & -0.06 \\
E66A $^{*}$ & 138.03 & 138.09 & 0.06 \\
E26* $^{*}$ & 140.93 & 140.99 & 0.06 \\
E8A* $^{*}$ & 141.68 & 141.56 & -0.12 \\
\hline
\end{tabular}

*: Recording by Royal Irrigation Department in Thailand.

$\dagger$ : Recording by Department of Alternative Energy Development and Efficiency (formerly the Department of Energy Development and Promotion) in Thailand.

Table 3. Accuracy assessment of 'non-damaged' and 'damaged' paddies

\begin{tabular}{|c|c|c|c|c|c|}
\hline \multirow[t]{2}{*}{ Classified data } & \multicolumn{2}{|c|}{ Reference data } & \multirow[t]{2}{*}{ Row total } & \multirow{2}{*}{$\begin{array}{l}\text { User's accuracy } \\
(\%)\end{array}$} & \multirow{2}{*}{$\begin{array}{c}\text { Kappa } \\
\text { per } \\
\text { category }\end{array}$} \\
\hline & NDP & DP & & & \\
\hline NDP & 140 & 19 & 159 & 88.1 & 0.74 \\
\hline DP & 21 & 120 & 141 & 85.1 & 0.72 \\
\hline Column total & 161 & 139 & 300 & & \\
\hline Producer's accuracy (\%) & 86.9 & 86.3 & & & \\
\hline
\end{tabular}

NDP: non-damaged paddies, DP: damaged paddies.

Note: number of pixels correctly classified $=260$; overall classification accuracy $=87 \%$.

Overall Kappa statistic $=0.73$. 
aged paddy and damaged paddy classes were over $85 \%$, which are comparable to the accuracy attained by using multi-temporal RADARSAT data for the central-western area of the Korean Peninsula ${ }^{14}$.

\section{Results and discussion}

\section{Rice damages}

For estimating the rice production after flooding, we used the lowland rice yield of 2.7 tonnes/ha with its net income of $106.62 \mathrm{US} \$ / \mathrm{ha}^{23}$ (based on US\$ 1 equals to 45 Thai Bahts). From Table 4, the loss of production from the damaged paddies was 37,800 tonnes, which would have earned US\$ 1.49 million, while the total rice produced from the non-damaged paddies was 55,242 tonnes, which was valued at US\$2.18 million. Based on the damaged paddy estimates $(35,477 \mathrm{ha})$ from the Department of Agricultural Extension, the government paid a total of US\$ 1.19 million in compensation at a rate of 33.75 US\$/ ha, while our damaged paddy estimates (14,000 ha) would have amounted to a payment of US\$ 0.47 million. Thus it seems that the government overestimated the degree of flooded-paddy damage.

\section{Recommendation of appropriate rice varieties for reducing the loss of rice production due to flood damage}

Deep-water rice and floating rice can grow well even in serious flooding (see Table 1) because their stems and leaves can elongate in flood water ${ }^{23}$. Previous studies ${ }^{5,24}$ and the 30-year water level records (see Fig. 3(c)) suggest that the 2001 flooding was considered an average flooding. Consequently, we can use this flood event to recommend the appropriate rice varieties in order to reduce the loss of rice production. Thus the damaged paddies $(14,000$ ha) were analyzed by overlaying with the flood frequency map produced in 2005 by the Land Development Department, resulting in three zones of flood frequencies in ten years: Zone A, flooding 8-to-10 times; Zone B, flooding 4-to-7 times; and Zone C, flooding less than 3 times (Fig. 7(b)).

For recommending the appropriate rice varieties, these three zones of damaged paddies were further analyzed with: (1) water depths; (2) compensation rate; and (3) income rates (Fig. 4 (h)). For the areas in Zones A and $\mathrm{B}$ the farmers are recommended to grow the deep-water rice and floating rice in the water depth of $80-150 \mathrm{~cm}$ $(5,570 \mathrm{ha})$ and deeper than $150 \mathrm{~cm}(5,412 \mathrm{ha})$, respectively. On the other hand, in the areas of Zone C (3,018 ha) farmers may take the risk of planting the lowland rice varieties for higher income (Table 5(A)). Therefore, of the damaged paddies (14,000 ha), 10,982 ha $(5,570+$ $5,412)$ are recommended for flood-tolerant rice verities and 3,018 ha for lowland rice varieties (Fig. 8), with the anticipated income of US\$ 0.77 ( 0.45 from deep-water rice +0.32 from floating rice) million and US\$ 0.32 million, respectively. Combining these anticipated incomes (US\$ 0.77 million +0.32 million) with the anticipated income from non-damaged paddies (US\$ 2.18 million) resulted in the total anticipated income of about US\$ 3.27 million, which farmers would have obtained.

In contrast, if the deep-water and floating rice varieties are not planted (Table 5(B)), 10,982 ha $(5,570+5,412)$ of lowland rice may be lost in Zones A and B. As a result, the government has to pay compensation of US\$ 0.37 million at a rate of $33.75 \mathrm{US} \$ / \mathrm{ha}$. In Zone C (3,018 ha) the rice production of US\$ 0.32 million may be obtained and rice production from the non-damaged paddies estimated at 20,460 ha would be US\$2.18 million, resulting in the total estimated rice production of US\$ 2.50 million. Even adding the compensation from government (US\$ 0.37), the total income from planting only lowland rice varieties is lower by US\$ 0.40 than growing the appropriate rice varieties. Consequently, the government should take measures to set the policy for recommending farmers to plant appropriate varieties in the damaged paddy areas.

\section{Summary and conclusions}

Using a RADARSAT image and DEM, we derived

Table 4. The total of obtained/lost rice production in the flood-affected paddies

\begin{tabular}{llccc}
\hline \hline $\begin{array}{l}\text { Category of } \\
\text { flood-affected paddies }\end{array}$ & Rice production & $\begin{array}{c}\text { Area } \\
\text { (ha) }\end{array}$ & $\begin{array}{c}\text { Quantity } \\
\left.\text { (Area } \times 2.7^{\dagger}\right) \\
(\text { Tonnes })\end{array}$ & $\begin{array}{c}\text { Value } \\
\left(\text { Area } \times 106.62^{\ddagger}\right) \\
(\text { US\$ in million)* }\end{array}$ \\
\hline NDP & Obtained & 20,460 & 55,242 & 2.18 \\
DP & Lost & 14,000 & 37,800 & 1.49 \\
\hline
\end{tabular}

NDP: non-damaged paddies, DP: damaged paddies.

${ }^{\dagger}$ : The average yield of lowland rice varieties (tonnes/ha).

$\$$ : The net income of lowland rice varieties (US\$/ha).

*: US\$ $1=45$ Thai Baht. 
Table 5. A comparison between total income with and without the recommendation of rice varieties

\begin{tabular}{|c|c|c|c|c|c|c|c|}
\hline $\begin{array}{l}\text { Category of } \\
\text { flood-affected } \\
\text { paddy } \\
\text { (I) }\end{array}$ & $\begin{array}{l}\text { Water depth } \\
\text { (cm) } \\
\text { (II) }\end{array}$ & $\begin{array}{c}\text { Flood frequency } \\
\text { zone }\end{array}$ & $\begin{array}{l}\text { Area } \\
\text { (ha) } \\
\text { (IV) }\end{array}$ & $\begin{array}{c}\text { Rice } \\
\text { varieties }\end{array}$ & $\begin{array}{c}\text { Income } \\
\text { rate } \\
\text { (US\$/ha) } \\
\text { (VI) }\end{array}$ & $\begin{array}{c}\text { Income } \\
(\mathrm{US} \$ \text { in } \\
\text { million }) \\
(\mathrm{VII}=\mathrm{IV} \times \mathrm{VI})\end{array}$ & $\begin{array}{l}\text { Total } \\
\text { income } \\
\text { (US\$ in } \\
\text { million) } \\
\text { (VIII) }\end{array}$ \\
\hline \multicolumn{8}{|c|}{ (A) With appropriate varieties } \\
\hline \multirow{3}{*}{ DP } & $>150$ & $A \& B$ & 5,412 & DWR & 59.56 & 0.32 & 3.27 \\
\hline & $>80-150$ & & 5,570 & FR & 80.38 & 0.45 & \\
\hline & $>80$ & $\mathrm{C}$ & 3,018 & LR & 106.62 & 0.32 & \\
\hline NDP & $\leq 80$ & All & 20,460 & LR & 106.62 & 2.18 & \\
\hline \multicolumn{8}{|c|}{ (B) Lowland rice varieties only } \\
\hline \multirow[t]{2}{*}{$\mathrm{DP}$} & $>80$ & $A \& B$ & $\begin{array}{c}10,982 \\
(5,570+5,412)\end{array}$ & $\mathrm{LR}, \mathrm{CP}$ & 33.75 & 0.37 & 2.87 \\
\hline & & $\mathrm{C}$ & 3,018 & LR & 106.62 & 0.32 & \\
\hline NDP & $\leq 80$ & All & 20,460 & LR & 106.62 & 2.18 & \\
\hline
\end{tabular}

A: Flood frequency zone A, every year, B: flood frequency zone B, every two years, C: flood frequency zone C, infrequent flooding.

DWR: Deep-water rice, FR: Floating rice, LR: Lowland rice, CP: Compensation for farmers paid by the government due to loss of lowland rice production caused by flooding.

the flood water depth, which was combined with the inundation tolerance of the rice varieties $(80 \mathrm{~cm})$, and the flood-affected paddies were classified into two categories; (1) damaged paddies (40\%), and (2) non-damaged paddies $(60 \%)$. The damaged paddies were further analyzed with: (1) flood frequencies; (2) water depths; (3) compensation rate; and (4) net income rates, for suggesting appropriate rice varieties. We successfully used remote sensing and GIS to assess the flood-affected paddies and to generate a map for recommending the appropriate rice varieties, which is essential for improving rice production as well as increasing the incomes for the flood-affected farmers and decreasing the government compensations.

\section{References}

1. Catling, D. (1992) Rice in deep water. The Macmillan Press LTD, UK, pp.542.

2. Chanket, U. (2004) An approach to the mapping of terrestrial ecosystem diversity in Chi Watershed. Master Thesis, Khon Kaen University, Thailand, pp.99 [In Thai with English abstract].

3. Confalonieri, R. \& Bocchi, S. (2005) Evaluation of CropSyst for simulating the yield of flooded rice in northern Italy. Eur. J. Agron., 23, 315-326.

4. Congalton, R. G. (1991) A review of assessing the accuracy of classifications of remotely sensed data. Remote Sens. Environ., 37, 35-46.

5. Dartmouth Flood Observatory (2006) The Dartmouth atlas of global flood hazard: E100N20. http://www.dartmouth.edu/ floods.

6. Department of Agricultural Extension (2004) The Royal
Thai Government announcement of the standard compensation scheme for farmer affected by natural flood hazard. Ministry of Agriculture and Cooperatives (MOAC), Thailand, 2-3 [In Thai].

7. Jongdee, B. et al. (2006) Improving drought tolerance in rainfed lowland rice: an example from Thailand. Agric. Water Manag., 80, 225-240.

8. Keith, K. A., Raskin, I. \& Kende, H. (1986) A comparison of the submergence response of deepwater and non-deepwater rice. Plant Physiol., 80, 479-482.

9. Khantiyawichai, K. (2004) An application of INFOWORKS RS model for flood routing in Chi Basin. Master Thesis, Khon Kaen University, Thailand, pp.267 [In Thai with English abstract].

10. Khush, G. S., Paule, C. M. \& De La Cruz, N. M. (1979) Rice grain quality evaluation and improvement at IRRI. In Proceedings of the workshop on chemical aspects of rice grain quality, 23-25 October 1978, International Rice Research Institute, Los Baños, The Philippines, 21-31.

11. Kongseree, N. (1979) Physicochemical properties of Thai rice varieties and methodology used in quality improvement. In Proceedings of the workshop on chemical aspects of rice grain quality, 23-25 October 1978, International Rice Research Institute, Los Baños, The Philippines, 183-190.

12. Land Development Department (2000) Digital soil map and soil descriptions. http:// www.ldd.go.th/menu_download/download-1.htm, MOAC, Thailand [In Thai].

13. Lanes, S. N. et al. (2003) Photogrammetric and laser altimetric reconstruction of water levels for extreme flood event analysis. Photogramm. Rec., 18, 293-307.

14. Lee, K. S. \& Lee, S. I. (2003) Assessment of post-flooding conditions of rice fields with multi-temporal satellite SAR data. Int. J. Remote Sens., 24, 3457-3465.

15. National Statistics Office (2001) Agriculture, forestry and fishery statistics. Ministry of Information and 
Communication Technology, Thailand [In Thai]. http:// webhost.nso.go.th:9999/nso/project/.

16. Oberstandler, R., Hönsch, H. \& Huth, D. (1997) Assessment of the mapping capabilities of ERS-1 SAR data for flood mapping: a case study in Germany. Hydrol. Process., 11, 1415-1425.

17. Okamoto, K., Yamakawa, S. \& Kawashiwa, H. (1998) Estimation of flood damage to rice production in North Korea in 1995. Int. J. Remote Sens., 19, 365-271.

18. Profeti, G. \& Machintosh, H. (1997) Flood management though Landsat TM and ERS SAR data: a case study. Hydrol. Process., 11, 1397-1408.

19. Provincial Agricultural Extension Office (2006) Rice production statistics of Kalasin, Maha-sarakarm and Roi-et Provinces from 2000 to 2005. MOAC, Thailand, pp.25 [In Thai].

20. Puckridge, D. W. et al. (2000) Production of rice and associated crops in deeply flooded areas of the Chao Phraya Delta. In Proceeding of International conference, The Chao Phraya Delta: Historical development, dynamics and challenges of Thailand's rice bowl, 12-15 December 2000, Kasetsart University, Bangkok, 51-85.

21. Puech, C. \& Raclot, D. (2002) Using geographical information systems and aerial photographs to determine water levels during floods. Hydrol. Process., 16, 1593-1602.
22. Sanyal, J. \& Lu, X. X. (2004) Application of remote sensing in flood management with special reference to monsoon Asia: a review. Nat. Hazards, 33, 283-301.

23. Sommut, W. (2003) Changes in flood-prone rice ecosystems in Thailand, crop year 2000-2001. Prachinburi Rice Research Center, Thailand, pp. 77.

24. Taragsa, N. (2004) An application of GIS and hydraulic model to flood plain inundation. Master Thesis, Khon Kaen University, Thailand, pp.129 [In Thai with English abstract].

25. Thai Junior Encyclopedia Project (1997) Thai junior encyclopedia, volume 3: rice, corn, cotton, rubber, wood, wood products, timber, weed, cattle, and elephant. http://www. kanchanapisek.or.th/kp6/BOOK3/chapter1/t3-1-11.htm [In Thai].

26. United State Department of Agriculture (2006) World rice trade (milled basis): exports and imports of selected countries or regions. http://usda.mannlib.cornell.edu/ MannUsda/homepage.do.

27. Werapaat, P. (1983) Knowledge of rice. MOAC, Thailand, pp.108 [In Thai].

28. Xu, K. et al. (2006) Sub1A is an ethylene-response-factorlike gene that confers submergence tolerance to rice. Nature, 442, 705-708. 